Historic, Archive Document

Do not assume content reflects current

scientific knowledge, policies, or practices. 


\section{Growing Food in Containers in the Tropics}

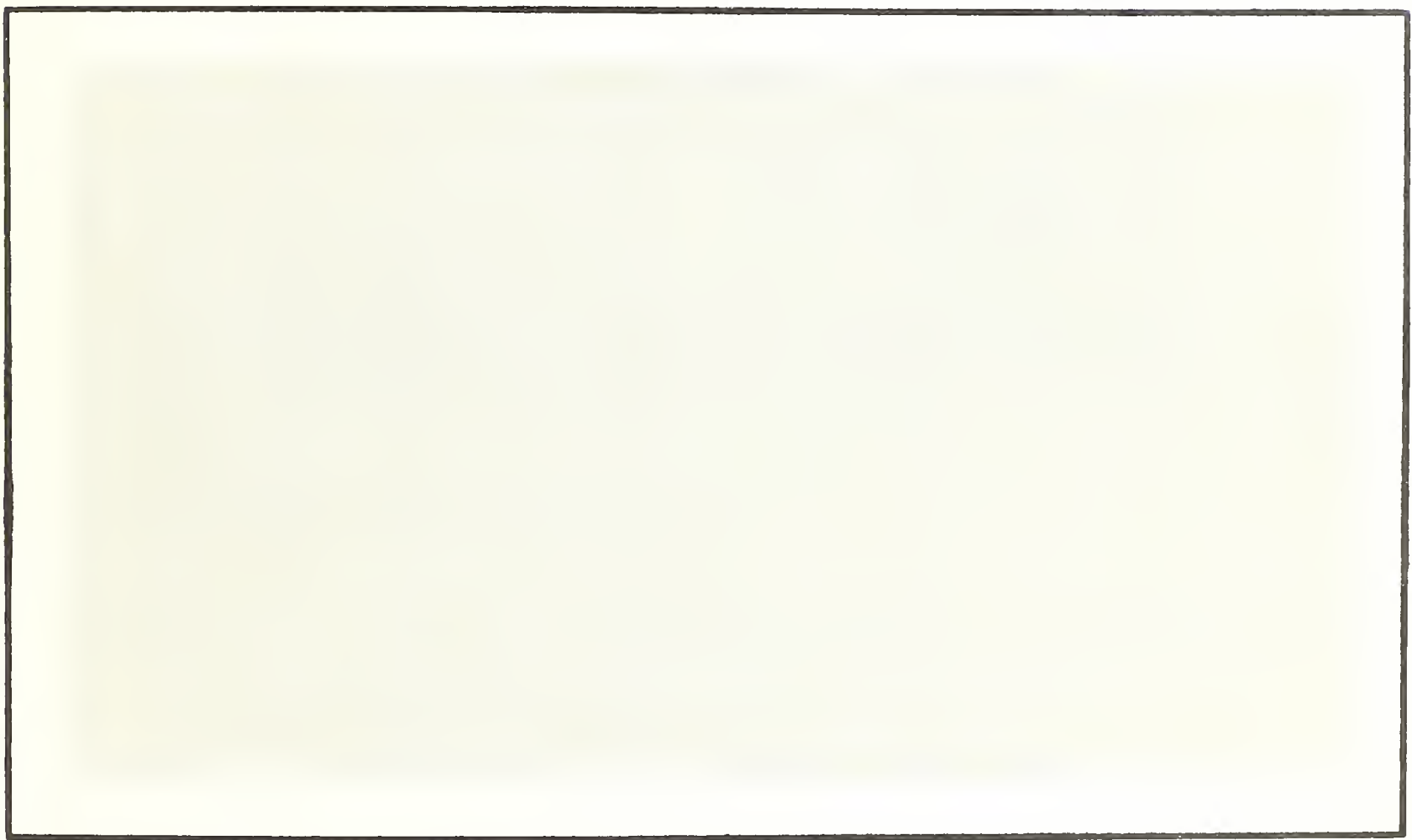

U.S. Department of Agriculture

Science and Education Administration

Agricultural Reviews and Manuals • ARM-S-13/January 1981 


\section{Related Publications}

This publication and the following publications about plants of interest to the tropical gardener are available free of charge from the Mayagüez Institute of Tropical Agriculture, Science and Education Administration, P.O. Box 70, Mayagüez, P.R. 00708:

Tropical Yams and Their Potential.

Part 2. Dioscorea bulbifera.

Part 3. Dioscorea alata.

Part 4. Dioscorea rotundata and Dioscorea cayenensis.

Part 5. Dioscorea trifida.

Part 6. Minor Cultivated Dioscorea Species.

Cultivation of Neglected Tropical Fruits With Promise.

Part 1. The Mangosteen.

Part 2. The Mamey Sapote.

Part 3. The Pummelo.

Part 4. The Lanson.

Part 5. The Canistel and Its Relatives.

Part 6. The Rambutan.

Part 7. The Durian.

Part 8. The Pejibaye.

Vegetables for the Hot, Humid Tropics.

Part 1. The Winged Bean.

Part 2. Okra.

Part 3. Chaya.

Part 4. Sponge and Bottle Gourds.

Part 5. Eggplant.

Part 6. Amaranth and Celosia.

Part 7. The Peppers.

Techniques and Plants for the Tropical Subsistence Farm. Agricultural Reviews and Manuals, Southern Series, No. 8. 


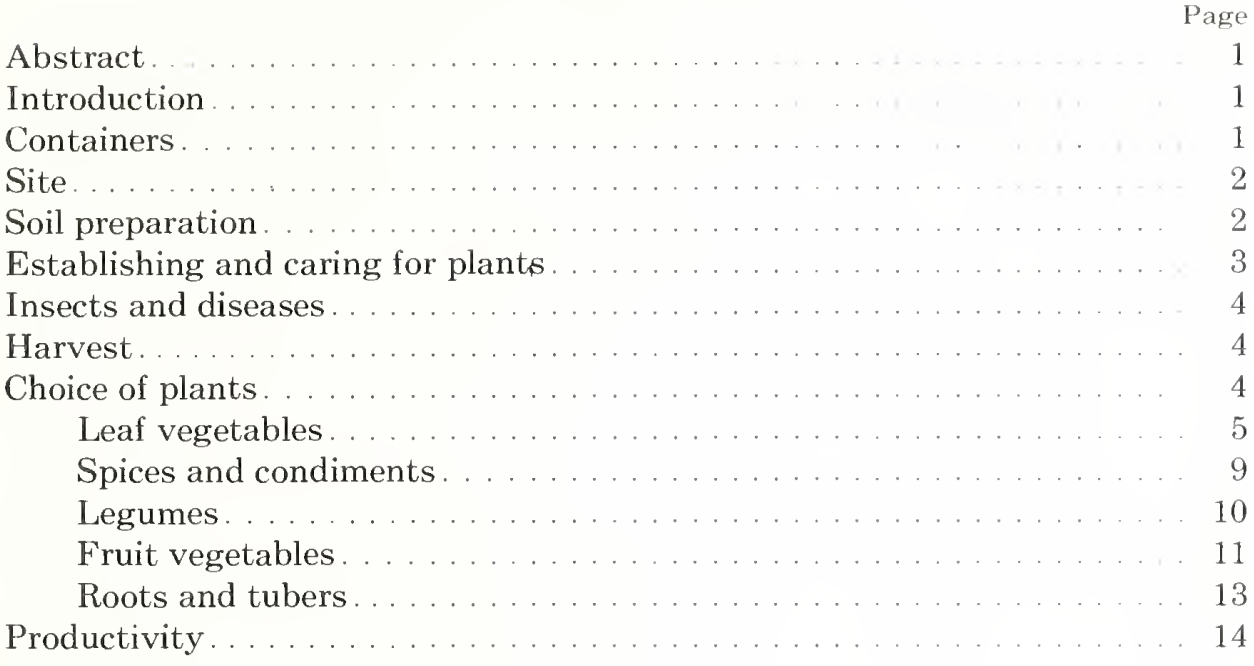

I L L USTRATIONS

Fig.

1. 'Oak Leaf' lettuce. . . . . . . . . . . . . . . . . . . . . . . . 5

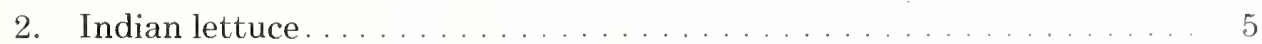

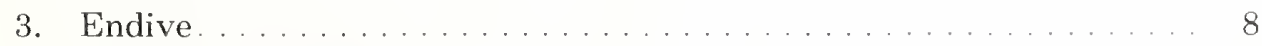

4. Sweetpotato foliage. . . . . . . . . . . . . . . . 8

5. Ceylon spinach . . . . . . . . . . . . . . . . . 8

6. Amaranth . . . . . . . . . . . . . . . . . . . . . . . . . . 9 9

7. Basil. . . . . . . . . . . . . . . . . . . . . . . . . . . 9

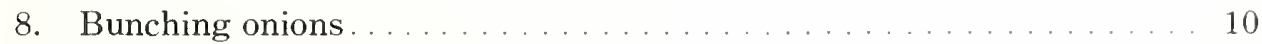

9. A good crop of tuberous leren roots . . . . . . . . . . . . . 13

\section{TA B L ES}

1. Simple control measures for common tropical pests of potted plants ... 4

2. Salad leaf vegetables grown in containers in the Tropics ......... 6

3. Leaf vegetables for cooking grown in containers in the Tropics . . . . . 7

4. Spices and condiments grown in containers in the Tropics . . . . . . . 10

5. Legumes found satisfactory for container production in the Tropics . . . . 11

6. Tomato varieties tested in containers in the Tropics .............. 12

7. Root and tuber crops tested in containers in the Tropics . . . . . . . . 12 


\title{
$v^{\prime \prime}$ Growing Food in Containers in the Tropics
}

\author{
By Franklin W. Martin and Ruth M. Rubertél
}

\begin{abstract}
A BSTRACT
$42^{2}$

This publication is designed to help those who live in the Tropics and whose space is limited to grow some of their own food in containers. It contains information on choosing containers and sites, preparing the soil, establishing and caring for the plants, avoiding insect and disease problems, harvesting, and the suitability of potential crops for container culture in the Tropics. If Index terms: container gardening, plant diseases, plant insects, small-scale agriculture, soil preparation, tropical agriculture, vegetables, yields.
\end{abstract}

\section{N T ROD UCTION}

One unfortunate fact of modern life is that when people become specialists at their own jobs they are often no longer able to perform essential common tasks that were once everyone's job - tasks such as producing food. People who no longer produce their own food must rely on the selection and quality of food in commercial markets. When prices rise, they have no choice except to pay more, buy less, or eat differently. Personal emergencies (such as job loss) cause even more hardship than they ordinarily would when those affected produce none of their own food.

Because foods produced at home are usually used fresh, they have a better appearance, flavor, and higher nutrient content than stored or processed foods. These foods can be grown with a minimum of exposure to chemical substances (such as pesticides) that have a harmful effect on the environment and perhaps on the human body as well. Thus, it is a distinct advantage to urban and rural dwellers alike to be able to produce as much food as they can on their own.

\footnotetext{
${ }^{1}$ Horticulturist and agricultural research technician. Mayagüez Institute of Tropical Agriculture, Science and Education Administration, U.S. Department of Agriculture, P.O. Bcx 70, Mayagüez, P.R. 00708.
}

For those who have no land or whose land is severely limited, food plants can be grown in containers that can be placed wherever there is enough light to support plant growth (windowsills, window boxes, shelves, pot stands within a room. hanging from the ceiling). The methods advocated in this publication are based in small part on literature now being developed for container gardening in the Temperate Zone, but most of the techniques were refined by the authors in 2 years of container gardening, indoors and out, in the hot, humid Tropics.

\section{CONTA I NERS}

It is not necessary to purchase containers; many that are usually thrown away (plastic bags, milk containel's, tin cans, plastic jugs, old baskets) are suitable for growing plants. If the containers are fragile, they can be reinforced with wire or string. Holes can often be covered by lining the container with sheet plastic. Containers can also be built from wood scraps.

The characteristics of the container influence the plant grown in it. Porous containers (such as clay pots) lose water by evaporation through the sides and thus are cooler and more suitable for plant growth than nonporous containers. They do, however, require more frequent watering. When 
dark, nonporous containers are used (such as black plastic bags) care must be taken that plants do not sustain root damage from overheating when exposed to strong sunlight.

Containers should have enough holes so that excess water can drain off easily. A tray or plate should be placed under the container to catch the water and keep it from dirtying or damaging the floor or anything else under the plants.

Container size is also very important. If plants are moved from place to place, large, heavy containers are not appropriate. Otherwise, permanently located containers are very productive and should be as large as possible. When they are very large, the plants grown in them may be grown by conventional techniques for growing plants in the ground.

Very small containers are not very productive and need much more attention than larger containers, but they might be suitable for herbs or other plants that are used only in small amounts. Portable containers should hold about 1 gallon (4 liters) of soil, an amount suitable for most green leaf vegetables and some short-lived annuals. Tomatoes, cucumbers, and sweetpotatoes do better in larger containers.

\section{S I T E}

The most important factor to be considered when choosing where to put plant containers is the availability of light. Sites that are never touched by direct sunlight should not be used for vegetables. Sites that receive direct sunlight for half the day or less are suitable for very succulent vegetables, but they will grow slowly there. Most vegetables grow best where sunlight is assured for most of the day. All plants should get as much sunlight as possible, but leafy vegetables tolerate shade better than roots and tubers. Fruit vegetables, including legumes, are the least shadetolerant plants.

Heat is an important factor in some sites. Overheating can occur when plants are grown where incident sunlight is reinforced by heat radiated by large walls; if winds cannot enter such places, heat can accumulate. If care is taken to insure that enough water is available in the soil, the excess heat will seldom damage plants, but in extreme cases heating can be reduced by shielding the plants with screens.

In some sites, especially on the top of buildings. wind may be a problem; it can cause mechanical damage or strain that can severely limit plant growth. Windbreaks can be constructed of sash or screen; to be effective in reducing wind injury, they should be about three times the height of the plants.

Containers should not be placed where they can fall on humans or animals or where they damage buildings by seepage. They should be in convenient places were they can be watered, tended, and harvested easily. As plants develop, they can be moved from one site to another as needed (to give the plants more or less light, heat, or rainfall). Esthetic needs may also be served; attractive plants can be placed in prominent sites.

Greenhouses are a special kind of site with unique advantages and disadvantages. Plants are well protected from wind and driving rain, but they may be exposed to high temperatures, high humidities, and severe attacks by insect pests that find greenhouse conditions very comfortable.

\section{SOIL PREPARATION}

The best soil for container gardening is friable; has good aeration and drainage, a high organic content, and a pH between 6 and 7 ; and is as free of diseases and pests as possible. If the best soil available fails to meet any of these criteria, it may have to be modified with additives. Substances such as perlite and vermiculite are often added to soil mixtures to increase aeration and drainage, and peat and sphagnum mosses add moisture-holding capacity without sacrificing aeration or drainage, but it is not necessary to purchase additives.

The homemade soil mixture should start with a natural soil (such as a loam or clay) that includes many fine particles. To this can be added sand and such organic material as rotted compost or rotted manure ( 2 parts soil to 1 part sand and 1 part organic material). Raw organic materials such as garbage and fresh manure should not be added to the soil mixture because they must deteriorate before they are useful, and while they are doing so, they may compete with the plants for the soil's nitrogen.

Charcoal in powdered or crushed form is a useful soil conditioner (it increases drainage and holds nutrients for plant use), but sawdust (a raw organic material) is not. Wood ashes can be used to neutralize acid soil, as can crushed shells 
(including eggshells), crushed coral or coral beach sand, and crushed limestone. Decaying organic material will tend to neutralize an alkaline soil.

The soil mixture need not be sterile. If the organic content of the soil is high, it will contain a wide variety of micro-organisms, most of which are beneficial. If disease or insect problems are persistent, soil can be sterilized in small quantities by baking it in shallow containers in an oven at $200^{\circ} \mathrm{C}$ for 30 minutes.

Because relatively small amounts of soil must furnish relatively large amounts of nutrients in container gardening, soil fertility (as well as texture) should be enhanced by adding compost, a natural fertilizer and soil conditioner made by decomposing organic wastes. Compost is pestfree because heat from the decomposition of the wastes kills most disease organisms.

If yard space is available, compost may be made in a bin or pile. Otherwise, it may be made in 20-gallon (76-liter) plastic garbage cans (or similar large, lightweight containers). Alternate layers of soil and organic material (with which such additives as crushed eggshells, bones, and mineral fertilizer may be included) are packed lightly in the garbage can, and if possible, the can is exposed to direct sunlight. The mixture should be well aerated, which can be accomplished by transferring it from one container to another every 2 or 3 days. Water may have to be added; the mixture must be kept wet but not soggy. The compost should be well rotted and suitable for mixing with soil and sand after 2 or 3 weeks.

Large containers (as large as is practicable) will be needed to store soil to be used in pots, soil to be recycled, finished compost, sand, and additives. Even if there is insufficient space to make composting practical, large containers will be needed to store soil and soil additives.

When composting is not practical, soil fertility can be maintained by adding a complete mineral fertilizer, which should contain nitrogen, potassium, and phosphorus in nearly equal proportions, and, if possible, important trace elements (such as calcium, boron, iron, magnesium, and sulfur). For each cubic foot (about 7 gallons or 30 liters) of soil, add one-half cup (125 grams) of mineral fertilizer when mixing soil to fill the pots. Small amounts of shredded raw crganic material can also be added to the mixture then. When plants have completed their growth and have been removed from the containers, the soil should also be removed and refertilized.

\section{EST A B L I S H N G A N D \\ CARING FOR PLANTS}

Large seeds ( 2 to 3 millimeters in diameter or more) may be planted directly in the container, but small seeds should be started in small containers and the seedlings transplanted later. A small quantity of sterilized soil is sifted finely into shallow, well-drained containers. The seeds are planted in rows, uniformly spaced at five times their diameter and at a depth of two or three times their diameter. Water is then added until the soil is saturated; excess water is drained off, and subsequently enough water is added to keep the surface slightly moist but never muddy. Seedling containers should be kept in a protected place where they cannot overheat, dry out, or be damaged oy people or pets. Sunlight is unnecessary until the seeds have germinated, after which the amount of sunlight should be increased gradually. Seedlings can be transplanted when they are 3 to 5 centimeters in height.

Some plants can be established from vegetative parts. Sweetpotatoes and Basella spinach, for example, are planted from cuttings (up to 20 centimeters) with two to three leaves. Others, such as bunching onions and chives, are propagated by offshoots. 'The clumps are uprooted, separated into individual plants, and then replanted. Cuttings and offshoots should be protected from strong sun and heat for 2 to 3 weeks.

Some plants, such as leaf vegetables, can be crowded and can be profitably planted several to a container, but others, such as tomatoes, produce better when planted only one per pot. Weeds should never be tolerated in containers and should be removed as soon as they are noticed, before they produce seed or otherwise spread.

A potted plant's main requirement is water: but correct watering is learned only by observation and experience. Too much water reduces root aeration and encourages disease, and too little leads to wilting and stunts growth. Plant size. container size, location, and weather affect the amount of water needed. In general, little water is needed by small plants or by plants in shady. locations, or on cool days. Conversely, relatively large amounts of water will be needed by large plants or by plants in sunny locations, or on hot days. Water need not be applied every day, but plants should be checked once or twice a day to see if they need watering. Keep in mind that small pots drain more rapidly than large ones. 
Table 1.- Simple control measures for common tropical pests of potted plants

\begin{tabular}{|c|c|}
\hline Pest & Control \\
\hline Snails, slugs. & $\begin{array}{l}\text { Place small boards on ground; check } \\
\text { daily and remove pests by hand. }\end{array}$ \\
\hline Caterpillars, worms & Remove by hand. \\
\hline Aphids ........... & Spray foliage with water. \\
\hline Mealybugs. & Remove with alcohol swab. \\
\hline Mites..... & Wash foliage with detergent. \\
\hline Black flies. & $\begin{array}{l}\text { Reduce watering so that soil sur- } \\
\text { face dries. }\end{array}$ \\
\hline
\end{tabular}

store less water, and are more easily overheated. Small plants in large containers are especially likely to be overwatered.

Watering devices can be purchased that will water a pot continuously for as much as 1 or 2 weeks, or wicks can be purchased or made from ropes to absorb and transport water from a saucer or basin below the container to any part of the container.

\section{INSECTS AND DISEASES}

Vegetables in containers are often attacked by insect pests. Large insects such as caterpillars can often be removed by hand and destroyed, and small ones such as aphids can often be removed with a water spray, by washing the foliage under the water tap, or with a soft cloth. Insects are sometimes removed by placing in a hotter or cooler location. Severely infested plants should not be left to infest other plants; if pests cannot be removed with simple treatments, it is best to remove and destroy the plant. Some common pests and suggested treatments are given in table 1.

Diseases are much more difficult to control. If the disease is not extensive, diseased parts can be removed and destroyed. If it is extensive, the plant will have to be destroyed and the soil sterilized. Infected soil can be recycled after being heated thoroughly (see "Soil Preparation"). Containers can be sterilized in an oven right along with the soil, and small containers of soil can be sterilized by pouring boiling water over them. A plant's location can also be changed to try to reduce opportunities for the disease to grow. (Diseases invariably will thrive better in one condition, such as heat or cold, sun or shade, than in another.) Some disease organisms, such as those causing black soot and anthracnose, can be washed off the foliage.

Symptoms will not always tell you the cause of the trouble. Yellow foliage can be caused by nutrient deficiency or overwatering as well as by disease organisms. Spots on the leaves may be caused by fungi, bacteria, or insect bites. If roots rot or plants wilt for unexplained reasons, it is best to assume the presence of a disease and sterilize the soil before reusing it.

\section{H A R V E S T}

For best flavor, vegetables should be harvested just before use and when they are at the right stage of development. Harvested vegetables should be removed from the sun as soon as possible. If they are to be stored, they should first be washed to remove dirt and pests.

Some vegetables are harvested only once. Leafy vegetables are harvested repeatedly, by one of two techniques. The older, stronger-tasting leaves can be harvested frequently, leaving shoots for further growth, a technique that maximizes yield. A milder, more tender product is obtained by removing the shoot and young leaves. Although there is subsequent new growth, it may take longer to become harvestable.

\section{CHOICE OF PLANTS}

The plants chosen for container gardening should yield well when grown in pots. Any vegetable can be grown in a container if its conditions for growth are met, but plants differ in their ability to grow and to produce worthwhile amounts of edible materials when container grown. To some, the novelty of some plants may compensate for low yields, but we recommend species and varieties of plants on the basis of their ability to produce useful quantities of edible material in a reasonable time. The best plants are those that can be harvested frequently over a long period of time.

All of our recommendations are based on 2 years of continuous experimentation. All plants were grown under two conditions: (1) in a greenhouse with warm night $\left(20^{\circ}\right.$ to $\left.24^{\circ} \mathrm{C}\right)$ and high daytime $\left(30^{\circ}\right.$ to $\left.35^{\circ} \mathrm{C}\right)$ temperatures, and $(2)$ on an outdoor bench, in full sun, subject to heavy rains during the tropical rainy season (outdoor temperatures 


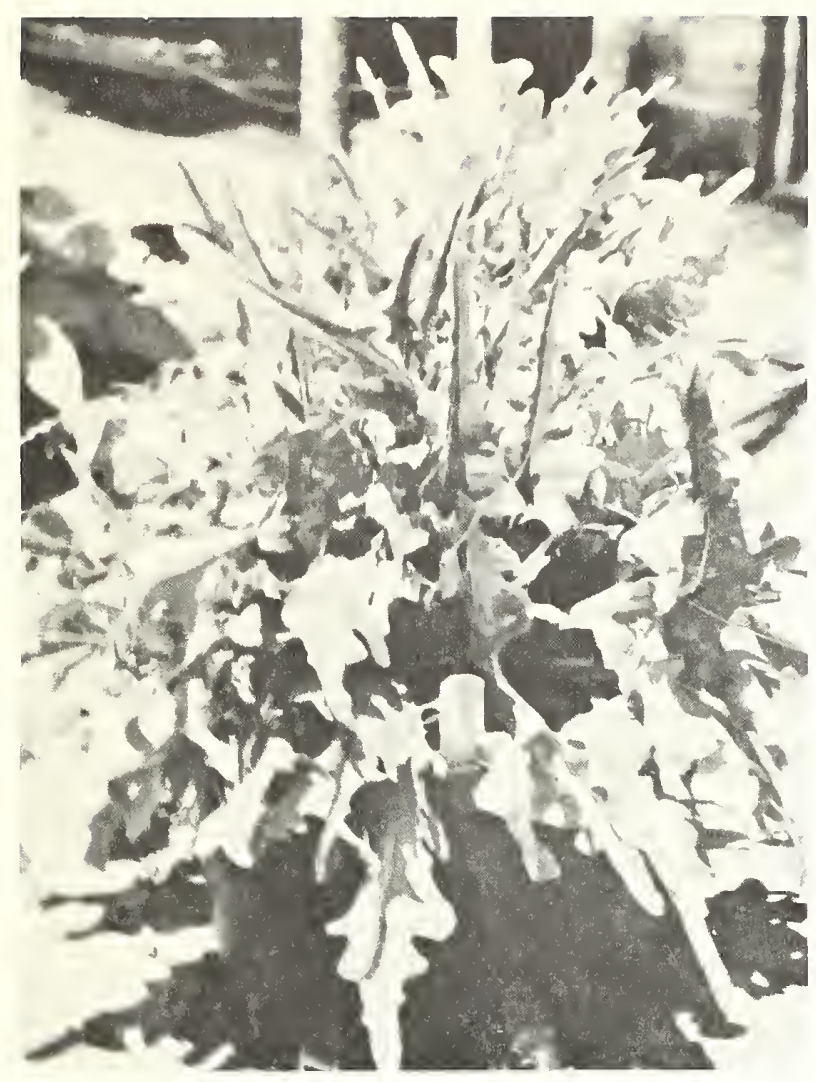

Figure 1. - 'Oak Leaf' lettuce is rapid growing and prolific, but short lived.

ranged from $10^{\circ}$ to $30^{\circ} \mathrm{C}$ ). All plants were watered as needed.

All plants were grown in plastic pots containing about a gallon (4 liters) of soil. The soil mixture contained 2 parts river loam, 1 part sand, and 1 part rotted sugarcane filter press cake (compost). No mineral fertilizers were used at any time. Small bamboo poles up to a meter in length were used as trellises for vines and support for weak plants. No chemical insecticides or fungicides were used; insects were removed by hand or controlled with direct water sprays. Vegetables were harvested at least three times each week, and harvested produce was weighed and recorded. The pots were maintained until the plants ceased to produce or (as in the case of some persistent yielders) until a year had elapsed.

We tested a wide range of vegetables, including some varieties recommended as small or midget, but we did not attempt to try all vegetable varieties available in seed catalogs or in our own stocks. The best vegetables are rated outstanding (those that are highly productive and dependable); others

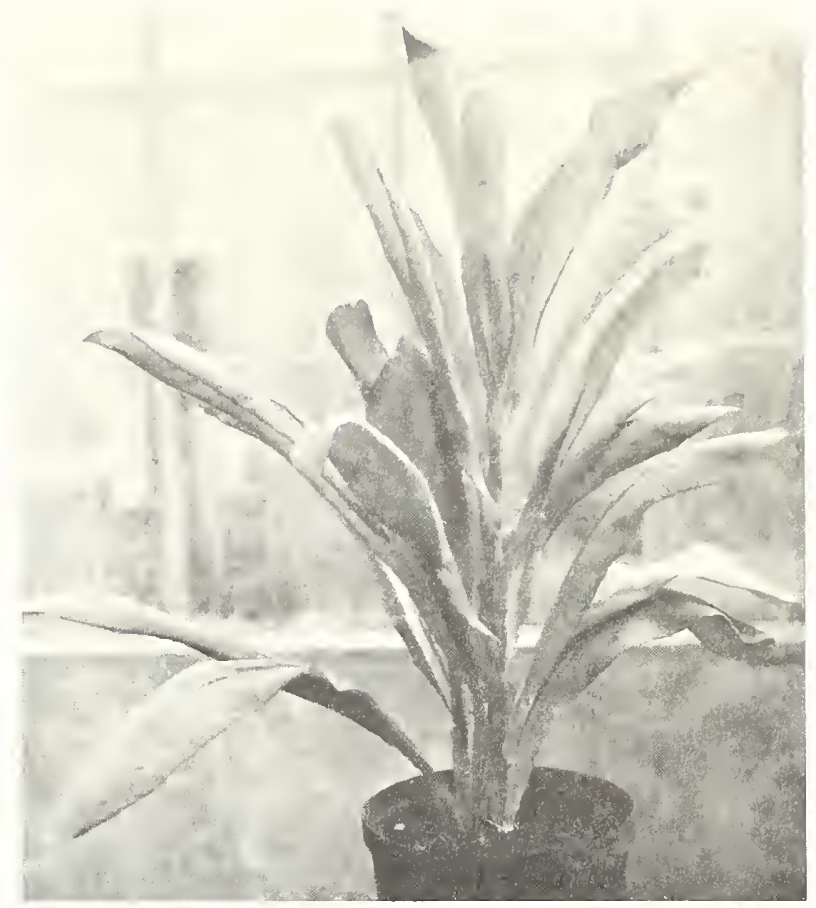

FiguRE 2, - Indian lettuce grows well throughout the year in the Tropics.

are rated satisfactory or unsatisfactory for the environment they were tested in.

\section{LEAF Vegetables}

Leafy vegetables, whether they are the kind used raw or cooked, were the most successful group of plants tested; many were outstanding. They tended to produce large quantities of edible materials over a long period of time, and some were perennial for almost so) in their growth habit.

The most successful salad vegetables were leaf lettuce (Lactuca sativa L.), Indian lettuce (Lactuca indica L.), and endive (Cichorium endivia L.) (table 2). Older, sound leaves should be harvested once or twice a week, and three or four pots of different-age plants should serve the needs of a family of four. All of these can be produced year round in the Tropics; Indian lettuce and endive can be grown in full sunlight, but lettuce needs some shade. None of these plants had serious insect or disease problems in our plantings.

Typical varieties of loose-leaf lettuce and heading varieties that were harvested as loose leaves yielded moderately. A few varieties, notably 'Mignonette'

(Continued on page 8.) 


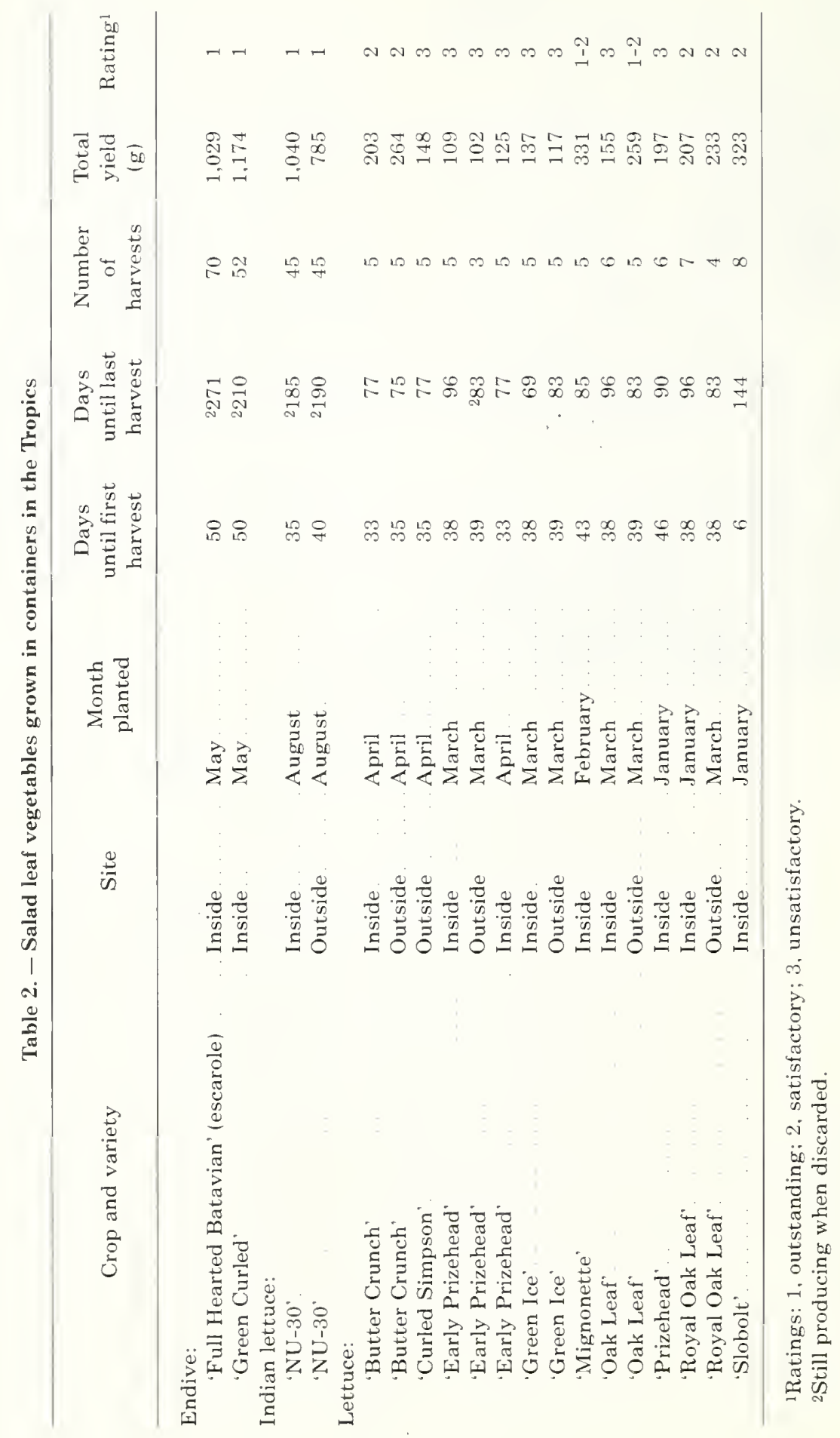




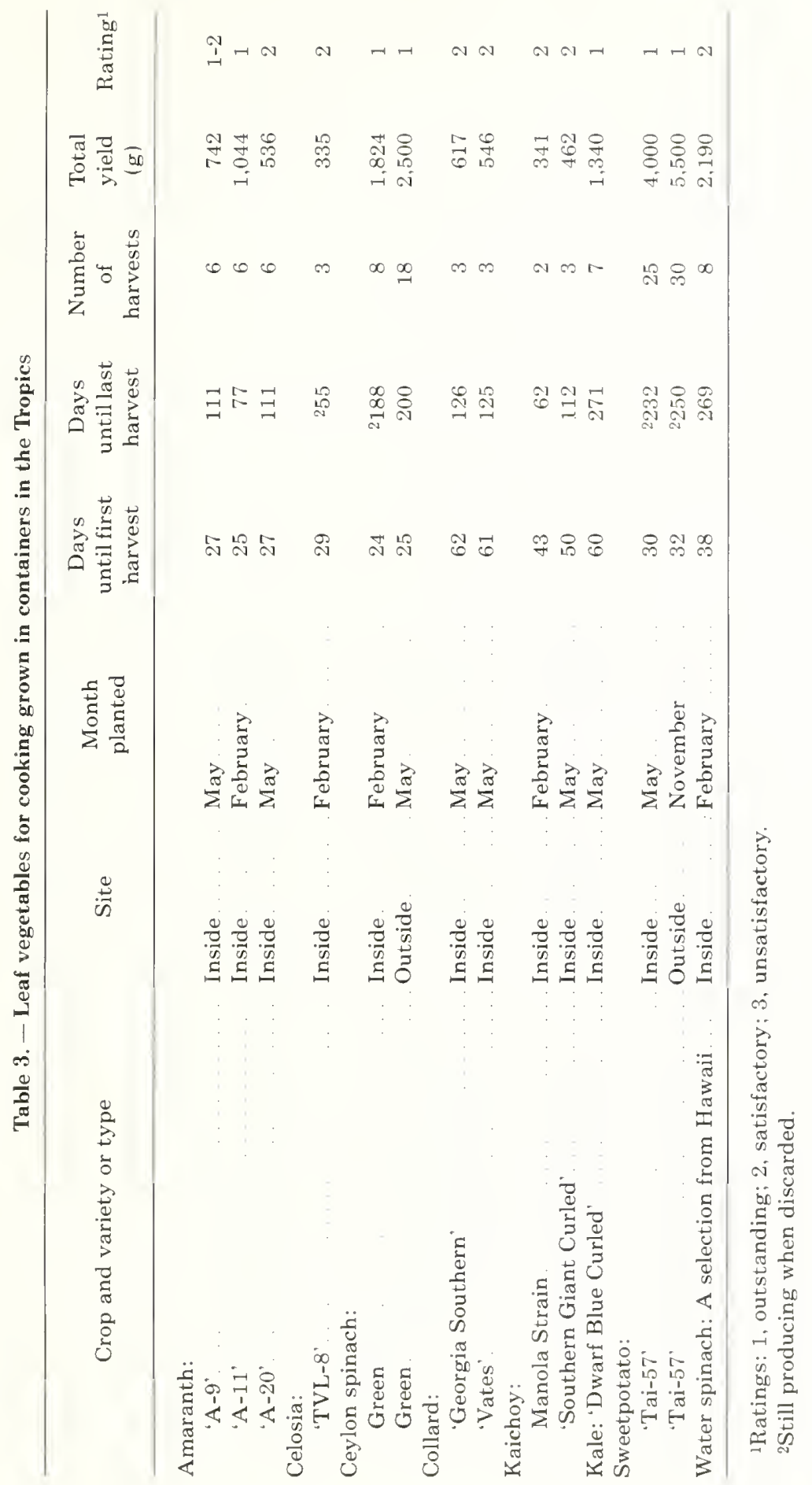




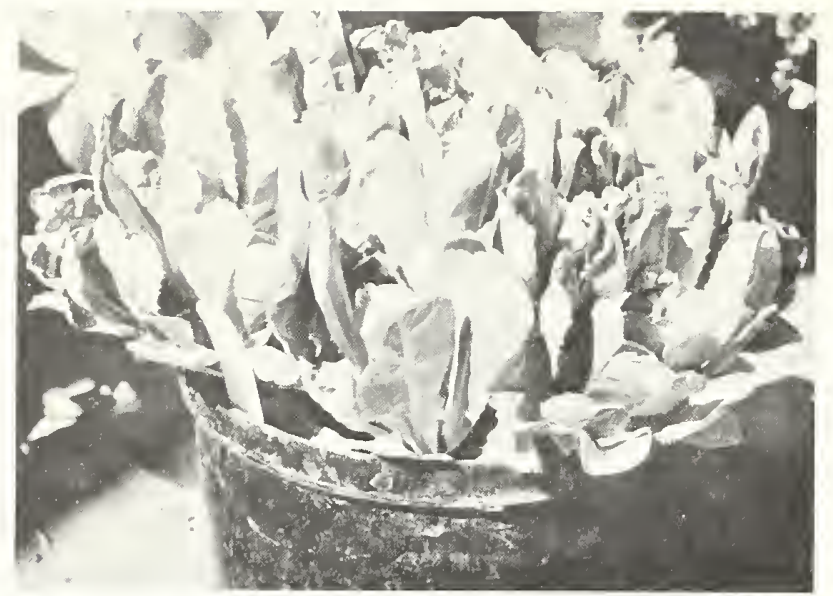

FIGURE 3, - Endive, a dependable, high-yielding salad green

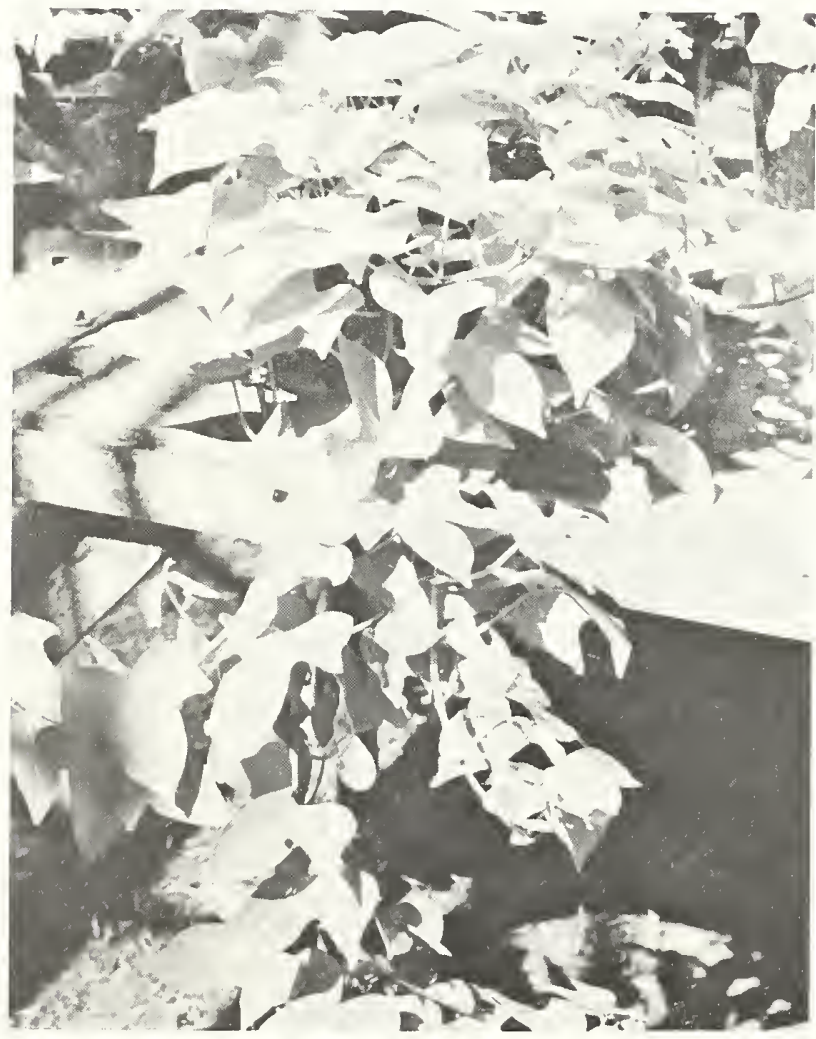

Figure 4 - Sweetpotato foliage is as useful as the tuberous root

and 'Oak Leaf' (fig. 1), were considered outstanding despite only moderate yields because of the high quality of the product. Five or six lettuce plants per pot are recommended.

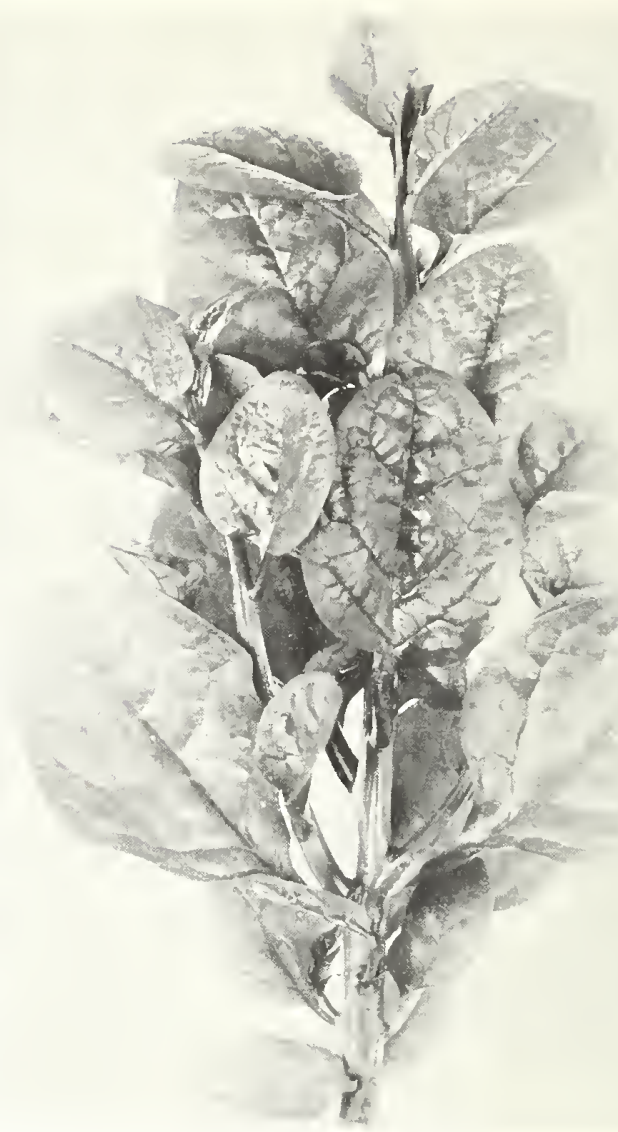

FIGURE 5. - Ceylon spinach is vigorous and productive.

Indian lettuce (fig. 2) proved to be an exceptional vegetable for container production. The plants are large, vigorous, and long lasting. The pale- to dark-green leaves are somewhat bitter, but a taste for them is quickly acquired. Three plants per pot are recommended.

Both varieties of endive (fig. 3) tested were outstanding both indoors and out during all seasons, even in full sunlight. Yields were excellent, quality was high, and endurance superb. Harvest can continue even during and after flowering. Three plants per pot are recommended.

Cooking-type leaf vegetables were also quite successful (table 3). The most vigorous and productive were sweetpotatoes [Ipomoea batatas (L.) Lam.] (fig. 4), of which many types were tested. We planted four to six cuttings in each pot, and all produced large quantities of edible leaves both inside and outside. (The vines become very long and do well when allowed to hang over walls or balconies or from hanging baskets.) But 


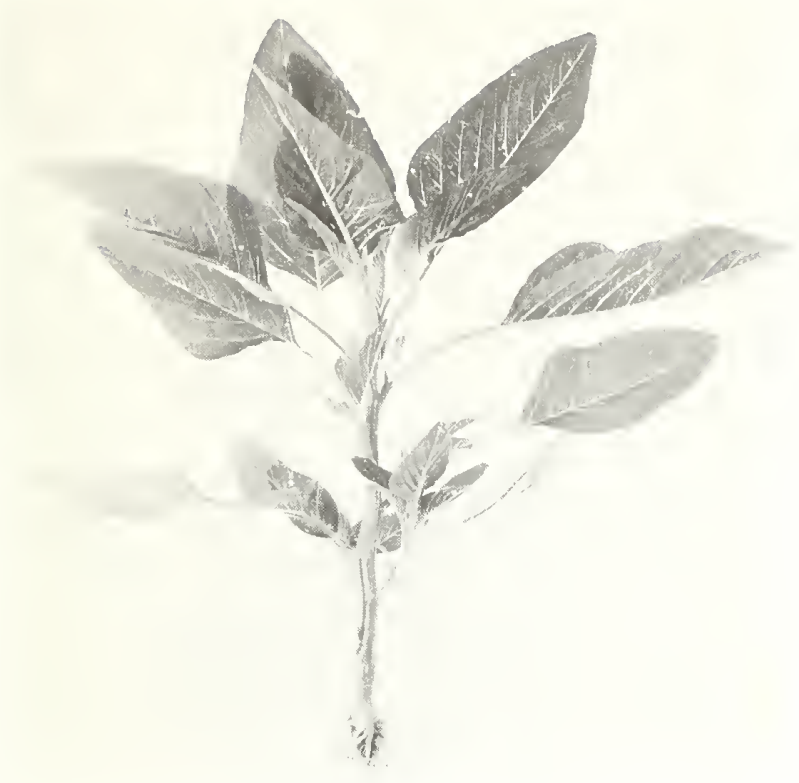

FIGURE 6. - Amaranth, a good cooked green.

insect pests occurred frequently and were difficult to control, especially inside the greenhouse. Water spinach (Ipomoea reptans Poir.), planted from seed, four to five plants per pot, also produced very large quantities of leaves, especially inside. but insect pests always limited the use of this species.

Ceylon spinach (Basella rubra L.) (fig. 5) is also very productive and takes little care. It can climb as a very productive vine if trellised and is easily maintained in less productive bush form by pruning. One cutting per pot is sufficient. It produces continuously and equally well inside and out, and although it flowers during winter months, it continues to produce. Ceylon spinach should not be used more than once a week because its oxalic acid content is high foxalic acid interferes with the body's calcium uptake and chronic oxalic acid intake can lead to calcium deficiency).

Amaranths (Amaranthus spp.) (fig. 6) grow very rapidly and produce fair to excellent leaf crops in three to four harvests, but their useful life is short. Two to four should be planted per pot. Some varieties are quite decorative when young, but they eventually begin to flower and lose their charm. They produce much better indoors than outdoors, for they attract many insect pests. Celosia (Celosia argentea L.) is similar in taste but is slower growing, longer lasting, and more productive out of doors. A family of four can use five to six pots of amaranth or celosia.

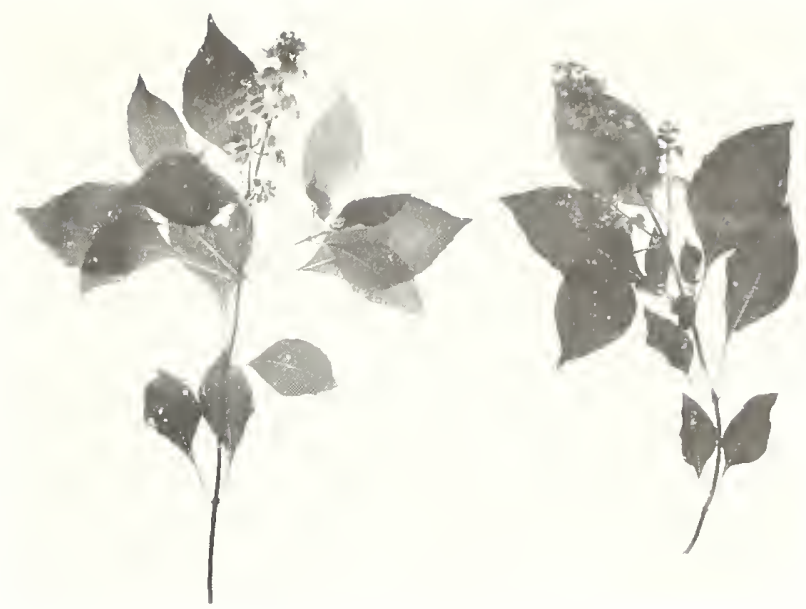

Figure 7. - Basil, a highly scented, useful spice.

Brassicas such as collard and kale (Brassica oleracea L. var. acephela) and kaichoy (Brassica juncea L.) are normally thought of as cool-weather crops, but they can produce magnificent yields of edible leaves vear round, inside or out. They can stand partial shade, have a minimum of insect and disease problems, and are attractive and nourishing. Each should be planted one to three per pot. We suggest growing all three to provide variety and protection against crop failure. perhaps a total of 10 pots per small family.

Some brassicas, such as cabbage (Brassica oleracea L. var. capitata) and Chinese cabbage (Brassica chinensis L.) were found to be unsatisfactory in containers; they may be grown there. but much less profitably than the more successful brassicas.

\section{Spices And Condiments}

Several plants used as spices or condiments were grown in containers, inside and out: basil (Ocimum basilicum L.) (fig. 7), bird pepper (Capsicum frutescens L.), chives (Allium schoenoprasum L.), cilantro (Eryngium foetidum L.), false oregano (Coleus amboinicus Lour.), ginger (Zingiber officinale L.), horseradish (Cochlearia armoracia L.), horseradish tree (Moringa oleifera Lam.), and parsley (Petroselinum crispum Nym.). Most proved to be excellent for container production (table 4). Their products (usually leaves, but in some cases roots) are used frequently but only in small quantities, so that in most cases only one pot (with one to five plants) of each herb is neces- 

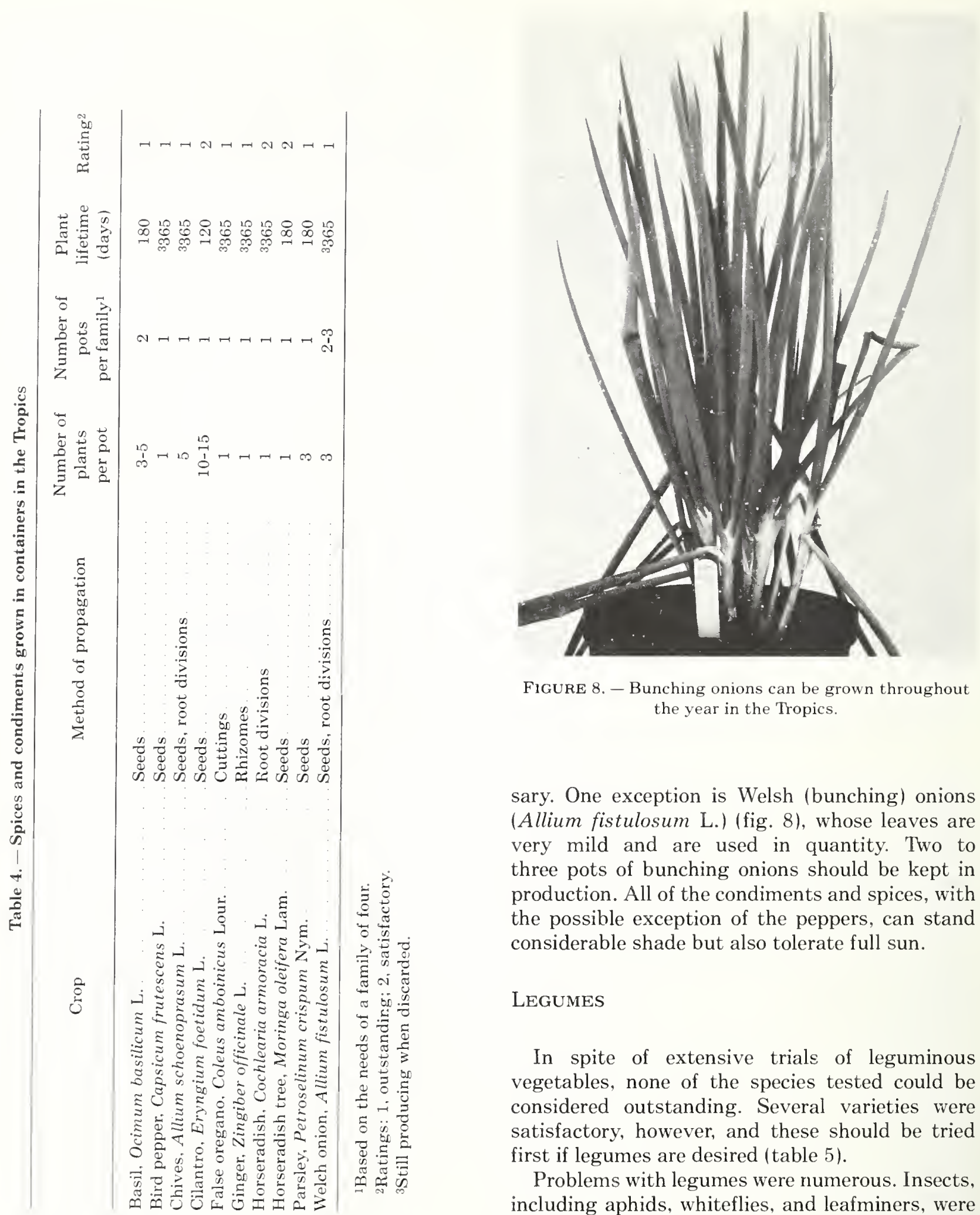

Figure 8, - Bunching onions can be grown throughout the year in the Tropics.

sary. One exception is Welsh (bunching) onions (Allium fistulosum L.) (fig. 8), whose leaves are very mild and are used in quantity. Two to three pots of bunching onions should be kept in production. All of the condiments and spices, with the possible exception of the peppers, can stand considerable shade but also tolerate full sun.

\section{LEGUMES}

In spite of extensive trials of leguminous vegetables, none of the species tested could be considered outstanding. Several varieties were satisfactory, however, and these should be tried first if legumes are desired (table 5).

Problems with legumes were numerous. Insects, including aphids, whiteflies, and leafminers, were common. But production was low even when no pests or diseases occurred. Poor production indoors was often a result of poor fruit set, probably from high temperatures. Outside the 
Table 5. - Legumes found satisfactory for container production in the Tropies

\begin{tabular}{|c|c|c|c|}
\hline Crop and variety & Site & $\begin{array}{l}\text { Total yield }{ }^{1} \\
\text { (g) }\end{array}$ & Rating $^{2}$ \\
\hline \multicolumn{4}{|l|}{ Common bean: } \\
\hline 'Bush I3lue Lake' & Inside. & 57 & $\mathrm{U}$ \\
\hline Green Podded Bush' & Inside & 57 & $\mathrm{~S}$ \\
\hline "Green Podded Bush Cherokee". & Inside & 32 & $\mathrm{U}$ \\
\hline MITA-NI-30' & Inside & 21 & $\mathrm{U}$ \\
\hline \multicolumn{4}{|l|}{ Lima bean: } \\
\hline Fordhook 242' & Inside & 54 & $\mathrm{~S}$ \\
\hline 'Fordhook 242' & Outside. & 80 & $\mathrm{~S}^{3}$ \\
\hline \multicolumn{4}{|l|}{ Mung bean: } \\
\hline $\mathrm{K}-97^{\prime}$ & Inside. & 59 & $\mathrm{~S}$ \\
\hline $\mathrm{K}-97^{\circ}$ & Outside. & 73 & $\mathrm{~S}^{3}$ \\
\hline \multicolumn{4}{|l|}{ IRice bean: } \\
\hline 'Surepod' & Inside & 47 & $\mathrm{~S}$ \\
\hline 'Surepod' & Outside & 80 & $\mathrm{~S}^{3}$ \\
\hline \multicolumn{4}{|l|}{ Soybean: } \\
\hline Jupiter & Inside & 7 & $\mathrm{U}$ \\
\hline 'Jupiter' & Outside & 50 & $\mathrm{~S}$ \\
\hline
\end{tabular}

${ }^{1}$ Total yields measured as dried seeds.

2Ratings: S, satisfactory: $U$, unsatisfactory.

${ }^{3}$ The best varieties of legumes tested.

greenhouse, the legumes lacked sufficient continuous vigor. One gallon (4 liters) of soil is not enough to sustain worthwhile yields of legumes.

The best varieties tested show promise for growth in larger containers. These are 'Fordhook 242 ', a very long-lived cultivar of lima bean (Phaseolus lunatus L.); 'K-97', a cultivar of mung bean ( $P$. aureus Roxb.); and 'Surepod', a variety of rice bean ( $P$. calcaratus Roxb.). Soybeans [Glycine max (L.) Merr.] often reverted to vine form in the hot greenhouse, but good yields were obtained at times. Varieties of soybean that may prove successful are 'Jupiter', 'Early Akita', 'Kahala', 'Kahnrich', and 'Kaiku'.

\section{Fruit Vegetables}

Tomatoes are favorite vegetables for greenhouse or container production, but they are difficult to grow in the hot, humid Tropics (either indoors or out). In the greenhouse, high temperatures impede fruit set. Poor results were obtained even with five varieties known to be heat resistant. The best, 'Toy Boy' and 'Patio Hybrid', were only marginally acceptable. 'Tiny Tim', a dwarf, determinate variety, is capable of bearing over an extended period in a greenhouse, but its fruits are very small.

Outdoors, yields were much better (table 6), and fair yields were obtained from several varieties.
When containers were placed on another much larger container of soil, the roots penetrated into the larger container, and yield was much higher, which showed graphically that 1-gallon (4-liter) containers are too small for adequate tomato plant growth. Probably 5 gallons (19 liters) of soil would be optimum. 'Toy Boy' hybrid proved to be an excellent, vigorous, long-living tomato when containers were large enough. 'Jubilee', a yellow tomato high in provitamin A, produced large fruits of very high quality. It yields acceptably where growing conditions are optimum. 'Campbell 35' produced very large numbers of good-quality, medium-sized fruit under several different conditions.

Many other tomato varieties were tested without success. Obviously, choice of variety is critical in container production of tomatoes. Small-fruited, indeterminate types (cherry tomatoes) were usually more productive than standard garden varieties if given enough container and growing space, and if trained to trellises. Thus under some conditions, tomatoes are excellent vegetables for containers. When space is most limited, the varietv "Tiny Tim' is recommended.

In general, other fruit-bearing vegetables produced poorly in comparison to leafy vegetables. They suffered from insects, disease, poor fruit set in the greenhouse, and a general lack of vigor.

All varieties of cucumber (Cucumis sativus L.) 
Table 6. - Tomato varieties tested in containers in the Tropics

\begin{tabular}{|c|c|c|c|c|}
\hline Variety & Site & $\begin{array}{c}\text { Number of } \\
\text { harvests }\end{array}$ & $\begin{array}{c}\text { Total yield } \\
\text { (g) }\end{array}$ & Rating \\
\hline 'BL 6807'. & Outside. & 5 & 200 & 3 \\
\hline 'Campbell $35^{\prime 2}$. & Outside. & 7 & 894 & 1 \\
\hline 'CIAS 161 . . & Outside & 5 & 211 & 3 \\
\hline 'Jubilee'. ...... . . . & Outside. & 6 & 898 & 2 \\
\hline 'Jung's Improved'. & Outside. & 6 & 323 & $1-2$ \\
\hline 'Park's Extra Early'2. & Outside. & 9 & 993 & 1 \\
\hline 'Patio Hybrid'. & Inside. . & 5 & 20 & 3 \\
\hline 'Patio Hybrid". & Outside. & 6 & 807 & 1 \\
\hline 'PI 262934' & Outside. & 5 & 403 & $1-2$ \\
\hline 'Saladette'. & Outside & 5 & 298 & 2 \\
\hline 'SG $916^{\circ}$ & Outside. & 4 & 299 & 2 \\
\hline 'Small Fry UFN Hybrid'2 & Outside & 17 & 1,796 & 1 \\
\hline 'Spring Giant U-F Hybrid'2. & Outside & 6 & 779 & 2 \\
\hline 'Tiny 'Tim' & Inside. . & 10 & 262 & $1-2$ \\
\hline 'Tiny Tim'?2. & Outside. & 13 & 1,102 & 1 \\
\hline ‘Toy Boy’. & Inside. . & 7 & 160 & 2 \\
\hline 'Toy Boy' & Outside & 16 & 3,540 & ${ }^{31}$ \\
\hline
\end{tabular}

1Ratings: 1, outstanding; 2, satisfactory; 3 , unsatisfactory.

${ }^{2}$ Roots penetrated into a larger container below the pots.

${ }^{3}$ Best variety tested.

Table 7.-- Root and tuber crops tested in containers in the Tropics

\begin{tabular}{|c|c|c|c|c|}
\hline Arrowroot: West Indian & Outside. & 35 & Needs container larger than 1 gallon. & 3 \\
\hline \multicolumn{5}{|l|}{ Carrot: } \\
\hline 'Kurola' ... & Inside. & 154 & Very slow growing & $2-3$ \\
\hline Leren: West Indian $\ldots$ & Outside. & 490 & $\begin{array}{l}\text { Transplant from field to pots in November in } \\
\text { Puerto Rico. }\end{array}$ & 2 \\
\hline Potato: 12 varieties. . . . . & Inside. . & 0 & Destroyed by microscopic white mites _... & 3 \\
\hline Radish: 'Early Scarlet Globe'. . & Inside. & 209 & Rapid growth, leaves can also be eaten & 2 \\
\hline \multicolumn{5}{|l|}{ Sweetpotato: } \\
\hline \multicolumn{5}{|c|}{ - } \\
\hline 'Crystal' & Inside & 125 & & $1-2$ \\
\hline 'Crystal' & Outside. & 178 & & $1-2$ \\
\hline
\end{tabular}

1Ratings: 1 , outstanding: 2, satisfactory: 3 , unsatisfactory. 
tested ('Bush Whopper Hybrid', 'Cherokee 7', 'Patio Pik Hybrid', 'Spacemaster', 'Suma', and 'Tiny Dill'), had high levels of disease and insects and very poor fruit set both indoors and out.

A few varieties of eggplant (Solanum melongena L.) were tested, and while they grow and set fruit reasonably well both indoors and out, the fruits are small and the yields are poor, making the final results disappointing. Varieties that are normally small fruited, such as 'Dusky', 'Midget', 'Morden', and 'White Jewel' are somewhat more useful than other varieties because they produce something useful over a long period of time. Five pots of one plant each are recommended.

Okra can be grown in containers, but small plants with short lifetimes suggest that 1-gallon (4-liter) containers are not large enough. Ten containers might produce enough for a family of four to have in the dinner two to three times per week for 1 or 2 months.

Many varieties of peppers (Capsicum spp.) were tested, and some good results were obtained, especially with chili peppers. But all the plants in some plantings were infected with a microscopic white mite that caused bronzing and stunting and killed growing tips. Once this mite infests containers, it is very difficult to produce peppers in them again. All peppers should be isolated from other potted plants. Plants with mite symp. toms should be destroyed and the soil recycled (through composting).

All the varieties of squash tested ('Burpee Hybrid Zucchini', 'Yellow Summer Crookneck', 'Dwarf Yellow Straight Neck', 'Emerald', 'Eat All', 'Baby Butternut', 'Table King', 'Golden Nugget', 'Waltham Butternut', and 'Bush Acorn') had a high level of insect and disease problems and produced very poorly both indoors and out. They too need larger containers.

\section{ROOTS AND TUBERS}

There are two classes of roots and tubers, starchy and nonstarchy. As a group, roots and tubers were not highly successful potted plants because to make a useful contribution to the diet, at least 10 to 20 pots of each kind must be grown. Otherwise, pot-grown starchy roots and tubers are chiefly novelties, and nonstarchy ones are of little food value unless used for their leaves.

Starchy roots and tubers include potato (Solanum tuberosum L.), cassava (Manihot esculenta

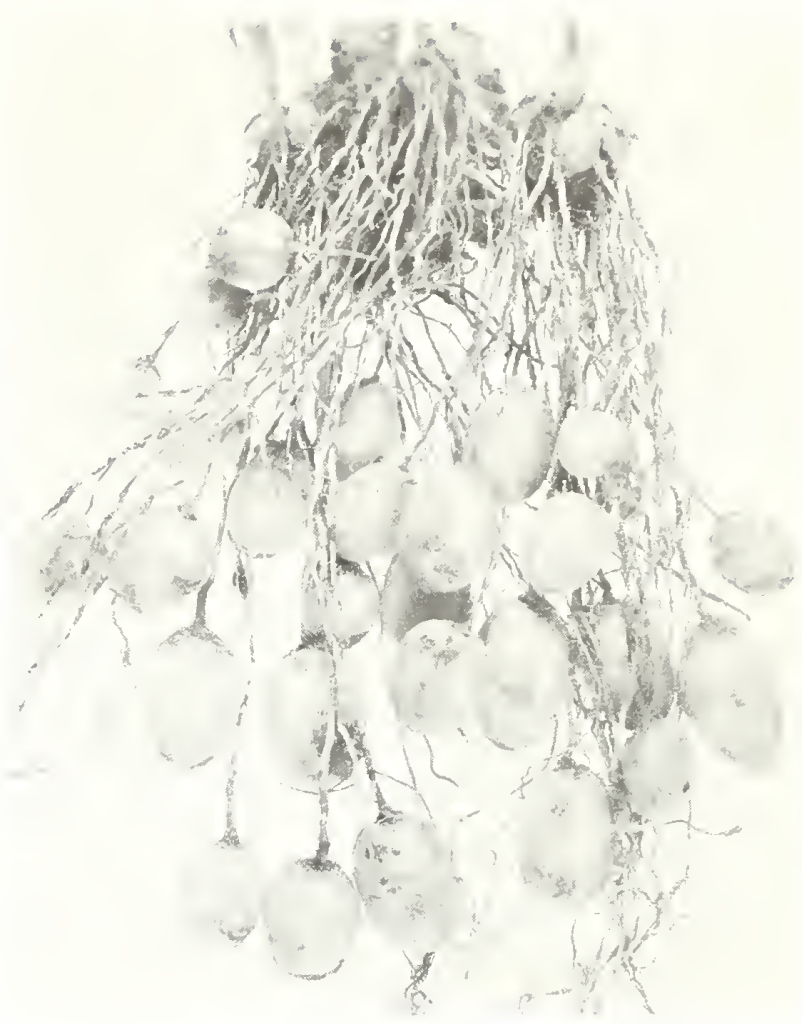

FIGURE 9. - A good crop of tuberous leren roots.

Crantz), sweetpotato, taro (Colocasia esculenta Schott), and many minor tubers (table 7), all of which are staple food plants because of the high nutritional value they contribute to the diet (in the form of starch or energy food). The best of these for pot culture is the leren (Calathea allouia Lindl.) (fig. 9), a little-known crop of the Caribbean. Yields of this crop in the field are normally low, but they can be increased significantly by digging entire, field-grown plants, dividing these into offsets, and replanting them in 1-gallon containers. They must be placed in full sun and watered frequently.

Sweetpotatoes can also be grown successfully in pots, mainly because its leaves can be used as well as its roots. The soil should be very sandy and two or three cuttings established in every pot. Success with sweetpotatoes depends on having varieties that produce well in containers; we prefer 'Tai 57', 'Redmar', and 'Painter'.

Potatoes might be successful in some circumstances, but the 12 varieties we tried were lost to the same microscopic white mite that destroyed the peppers. If potatoes are tried (one plant per pot), they should be grown in full sun. 
Nonstarchy tubers such as radishes, turnips, and the yam beans (table 7) add variety to the diet but have little nutritional value. Radish is success. ful because it can be used for its leaves as well as its roots. It can be grown in partial shade or in cool areas. Yam bean tubers can be eaten raw as a novelty, and the very young pods can be cooked. (Young yam bean pods give stomach aches to some people; a portion a week appears to be harmless.) One plant per pot is sufficient; the tubers can be large (up to $1 \mathrm{~kg}$ ).

\section{PRODUCTIVITY}

Container gardening can be very productive, but the gardener's expectations should be realistic. Naturally, he wishes to maximize his production, and production often looks poor. Yet when yields are calculated on a per-hectare basis, they are often very high, and sometimes sensational.

In our experiments each gallon container occupied less than 0.1 square meter. Thus, a yield of only 100 grams of edible produce from a pot is equal to a yield of 10 tonnes per hectare, a good yield in conventional agriculture. Container yields can be excellent if soil fertility is maintained, plants are cared for, and as much of the plants is used as possible.

Since some crops are produced more easily than others, some nutrients are produced more readily. A family of four producing food in 1001 -gallon (4-liter) containers could produce 100 percent of the vitamin $A$ and vitamin $C ; 20$ percent of the protein; 10 percent of the carbohydrate; 5 percent of the vitamin $\mathrm{B}_{1}$, vitamin $\mathrm{B}_{3}$, calcium, and iron; 2 percent of the vitamin $\mathrm{B}_{2}$; and 1 percent of the fat and vitamin $\mathrm{E}$ that they require.

A good proportion of these nutrients will come from leaves. The family can easily produce more leaves than it can eat. Thus, reasonable expectations for container gardening are to produce salads, cooked greens, and spices as needed and to grow other vegetables for variety in the diet. 

U.S. DEPARTMENT OF AGRICULTURE

SCIENCE AND EDUCATION ADMINISTRATION P. O. BOX 53326

NEW ORLEANS, LOUISIANA 70153

OFFICIAL BUSINESS

PENALTY FOR PRIVATE USE, \$3OO

NATIONAL AGRICULTURAL LIBRARY

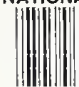

1023187730

POSTAGE AND FEES PAID

U. S. DEPARTMENT OF AGRICULTURE

AGR 101

FIRST CLASS 